\title{
Kebiasaan minum dan asupan cairan remaja di perkotaan
}

\author{
Dodik Briawan ${ }^{1}$, Tyas Rara Sedayu², Ikeu Ekayanti ${ }^{1}$
}

\begin{abstract}
Background: Human body requires water for the active and healthy life. Water is actually a nutrient, and there is a tendency that some people neglect its important roles for health. Water requirements can vary depends on physical activity, age groups, body weight, climate, and diet (energy intake).

Objective: The study aimed to identify drinking habits and to assess water intake and its adequacy of teenagers in urban.

Method: Cross-sectional study was conducted from May to June 2009 in high school SMAN 2 Bogor. The samples were healthy student at grade $X$ and XI. The number of sample were 83 students which calculated based on mean estimation. Food and beverages consumption was assessed with 2 × 24 hours recall during a week-day and a week-end. Meanwhile, the last week drinking habits was collected by interviewed. Statistical analysis used here was independent $t$-test.

Results: The average of water intake was $2582 \pm 834 \mathrm{ml}$, whereas $2939 \pm 922 \mathrm{ml}$ for boys and $2250 \pm 581 \mathrm{ml}$ for girls. The total water intake was from solid foods $(656 \pm 265 \mathrm{ml})$ and beverages (1927 $\pm 704 \mathrm{ml})$. The contribution of drinking water to the total water intake was $51 \%$ for boys $(1495 \mathrm{ml})$ and $58 \%$ for girls $(1311 \mathrm{ml})$. The average water adequacy was $132 \%$ for boys and $111 \%$ for girls.

Conclusion: The average of water intake was considerly adequate in teenagers, however there was still $24.1 \%$ of them consumed less than $90 \%$ of water adequacy.
\end{abstract}

KEY WORDS teenagers, water intake, drinking habits, urban

\section{PENDAHULUAN}

Air memiliki banyak fungsi antara lain sebagai pelarut, penyusun struktur sel, katalisator proses enzimatis, pengisi ruang antarsendi, pengatur suhu tubuh, berperan dalam peredaran darah, dan ekskresi sisa metabolisme. Air juga menjaga konsistensi fisik dan kimia pada cairan intrasel dan ekstrasel, sehingga berperan langsung dalam mengatur suhu tubuh (1). Keseimbangan air dan elektrolit tubuh akan mempengaruhi kemampuan termoregulasi. Suhu udara yang panas akan menyebabkan banyaknya cairan tubuh yang hilang melalui penguapan dan keringat. Apabila cairan tubuh tidak diganti maka akan menyebabkan dehidrasi dan defisit elektrolit (2). Air sangat penting bagi kehidupan manusia, namun konsumsi air seringkali diabaikan dalam diit sehari-hari (3).

Kandungan air tubuh berbeda antarmanusia tergantung pada proporsi jaringan otot dan jaringan lemak. Tubuh yang mengandung lebih banyak otot mengandung lebih banyak air dibandingkan tubuh yang mengandung banyak lemak (4). Tubuh manusia rata-rata tersusun atas $75 \%$ air dan $25 \%$ bahan padat. Otak tersusun atas $85 \%$ air dan sangat rawan jika mengalami dehidrasi. Seseorang yang mengalami kehilangan $40 \%$ lemak dan protein tubuh akan mampu bertahan hidup tetapi jika kehilangan $20 \%$ air dapat menyebabkan kematian (5).

Kebutuhan air meningkat seiring peningkatan usia. Secara normal, tubuh akan kehilangan cairan melalui urin, keringat, maupun feses. Untuk menjaga agar kondisi dan fungsi cairan tubuh tidak terganggu, kehilangan cairan tersebut harus diganti. Jika tubuh tidak cukup mendapatkan air atau terjadi kehilangan air sekitar $5 \%$ dari berat badan maka tubuh akan mengalami dehidrasi (6).
Kebutuhan air tiap orang berbeda-beda dan berfluktuasi tiap waktu. Hal tersebut dipengaruhi oleh berbagai faktor seperti jenis kelamin, usia, tingkat aktivitas, serta faktor lingkungan. Metode perkiraan kebutuhan air adalah berdasarkan umur, berat badan, asupan energi, asupan nitrogen, luas permukaan tubuh serta jumlah energi yang dikeluarkan. Di Indonesia belum tersedia data sebagai dasar perhitungan kebutuhan air, sehingga Widyakarya Nasional Pangan Dan Gizi (WNPG) 2004 mengacu pada rekomendasi Filipina yaitu untuk remaja dan dewasa (15-30 tahun) sebesar $40 \mathrm{ml} / \mathrm{kg}$ berat badan (BB) (7).

Survei di Singapura yang dilakukan Temasek Polytechnic dan Asian Food Information Centre (8) menunjukkan sebagian besar remaja umur 15-24 tahun tidak minum dalam jumlah yang cukup. Rata-rata laki-laki minum 1,5 liter cairan per hari, sementara perempuan minum 1,6 liter per hari, masih kurang dari jumlah yang dianjurkan yaitu 2 liter per hari atau setara dengan 8 gelas per hari. Hasil survei riset kesehatan dasar (Riskesdas) 2007 menunjukkan aktivitas fisik pada kelompok usia 15-24 tahun sebagian besar (52\%) tergolong rendah (9). Aktivitas fisik yang rendah tersebut di antaranya dapat menyebabkan berkurangnya konsumsi minuman.

Tujuan umum penelitian ini adalah mempelajari kebiasaan minum dan asupan cairan pada remaja laki-

\footnotetext{
${ }^{1}$ Departemen Gizi Masyarakat, Fakultas Ekologi Manusia Institut Pertanian Bogor (FEMA-IPB), JI. Lingkar Kampus, Kampus IPB Darmaga, Bogor 16680, e-mail: dbriawan@yahoo.com.

2 Rumah Sakit Siti Khodijah, JI Pahlawan No 260 Sepanjang, Sidoarjo, Jawa Timur.
} 
laki dan perempuan di wilayah perkotaan. Tujuan khusus penelitian adalah: 1) mengkaji kebiasaan minum pada remaja, 2) menghitung asupan cairan dan kontribusinya dari makanan dan minuman pada remaja laki-laki dan perempuan, dan 3) mengetahui kebutuhan dan kecukupan cairan pada remaja laki-laki dan perempuan.

\section{BAHAN DAN METODE}

Desain penelitian adalah cross-sectional study. Penentuan sekolah dilakukan secara purposive yaitu: 1) lokasi yang strategis, 2) kemudahan akses, dan 3) keragaman latar belakang siswa. Untuk itu dipilih SMA Negeri 2 Bogor yang memiliki delapan kelas paralel pada masing-masing tingkat, dan mempunyai fasilitas pendukung yang cukup lengkap. Pengumpulan data dilaksanakan bulan Mei - Juni 2009.

Jumlah sampel dihitung untuk memperkirakan rata-rata (estimation of mean), dengan asumsi standar deviasi (SD) asupan cairan $900 \mathrm{ml}$ (10), presisi 20\%, dan a sebesar 0,05 , sehingga diperoleh minimal sampel sebesar 78 orang. Kriteria sampel adalah: 1) berada dalam kelas reguler (ruang kelas biasa atau tidak ber-AC), 2) tidak sedang sakit diare, ginjal, demam berdarah, radang tenggorokan, 3) tidak sedang menjalani pengobatan penyakit ginjal atau diabetes mellitus.

Populasi penelitian adalah seluruh siswa kelas X dan XI di SMU Negeri 2 Bogor. Siswa kelas XII tidak diperkenankan menjadi sampel karena harus fokus untuk mempersiapkan ujian akhir. Masing-masing kelas $X$ dan $\mathrm{XI}$ terdiri dari 7-8 kelas dengan siswa sekitar 40 orang, sehingga total populasi 584 siswa. Setiap kelas dipilih secara acak sebanyak 6 orang, sehingga diperoleh 90 subjek. Sebanyak 7 subjek dikeluarkan karena tidak lengkap isian kuesionernya. Jumlah subjek yang dianalisis sebanyak 83 remaja yang terdiri dari 40 laki-laki dan 43 perempuan.

Jenis data yang dikumpulkan meliputi umur, jenis kelamin, tempat tinggal, jumlah uang saku, pengeluaran uang saku, pengukuran antropometri berat badan (BB) dan tinggi badan (TB), dan kebiasaan minum. Pengukuran kebiasaan minum meliputi pengeluaran untuk minuman, kebiasaan bekal minum, jenis dan jumlah minuman lainnya selama satu minggu yang lalu. Asupan cairan diperoleh dari data konsumsi makanan dan minuman yang dikumpulkan dengan metode food recall selama 2x24 jam dengan rincian 24 jam terakhir pada hari libur dan hari sekolah. Kebiasaan minum diperoleh dengan pengisian kuesioner oleh subjek dengan panduan peneliti. Alat bantu untuk estimasi jumlah minuman menggunakan gelas minuman plastik $(240 \mathrm{ml})$ sebagai ukuran standar.

Data yang diperoleh diolah dan dianalisis dengan menggunakan program software komputer. Konversi kandungan air pada makanan dan minuman menggunakan tabel komposisi zat gizi makanan (11). Kebutuhan cairan dihitung berdasarkan rumus Food and Nutrition Research Institute (FNRI) 2002 untuk usia 15-30 tahun adalah 40 $\mathrm{ml} / \mathrm{kg}$ BB (12). Kebutuhan cairan tersebut dibandingkan dengan asupan cairan, sehingga diperoleh persentase kecukupan cairan. Uji beda t-test dilakukan untuk mengetahui perbedaan rata-rata asupan cairan, kebutuhan cairan, serta kecukupan cairan antara remaja laki-laki dan perempuan.

\section{HASIL DAN BAHASAN}

\section{Karakteristik remaja}

Subjek berusia antara 15-17 tahun dengan ratarata $15,9 \pm 0,8$ tahun. Sebagian besar remaja $(48,2 \%)$ berusia 16 tahun dan sebesar $30,1 \%$ berusia 15 tahun. Rata-rata berat badan perempuan sebesar $52 \mathrm{~kg}$, lebih rendah dibanding rata-rata berat badan laki-laki yaitu sebesar $55 \mathrm{~kg}$. Usia serta komposisi otot dan lemak tubuh seseorang akan berpengaruh terhadap jumlah cairan tubuhnya $(4,6)$.

Rata-rata uang saku remaja adalah $\mathrm{Rp} 15.296 \pm$ 6.744 per hari. Sebagian besar remaja $(56,6 \%)$ memiliki uang saku Rp 10.000 - Rp 20.000 per hari. Uang saku yang dialokasikan untuk makanan dan minuman bervariasi sampai dengan Rp 15.000 per hari. Sebagian besar remaja $(51,2 \%)$ mengalokasikan Rp 5.000 - Rp 10.000 per hari untuk makanan dan minuman. Persentase uang yang dialokasikan untuk pangan bervariasi dengan rata-rata 44,2 $\pm 18 \%$ dari total uang saku. Remaja yang membawa bekal makanan dan atau minuman dari rumah, mengalokasikan sampai dengan Rp 5.000 per hari untuk membeli kue dan es sirup atau air putih atau teh kemasan di kantin sekolah. Kue yang paling sering dibeli yaitu martabak mini atau cireng (tepung singkong goreng) seharga Rp 1.500 per potong. Es sirup dapat dibeli dengan harga Rp 2.000 per gelas, dan air putih kemasan harga Rp 500 per gelas (240 $\mathrm{ml})$ atau $\mathrm{Rp} 1.500$ per botol $(600 \mathrm{ml})$.

\section{Kebiasaan minum remaja}

Seperti halnya kebiasaan makan, remaja memiliki kebiasaan minum air putih pada waktu-waktu tertentu. Sebagian besar remaja $(97,6 \%)$ minum air putih setiap saat ketika merasa haus. Sebanyak $57,8 \%$ remaja biasa minum air putih setelah pulang sekolah. Hanya 15,7\% remaja yang memiliki kebiasaan minum air putih setelah berolahraga. Sebanyak $19,3 \%$ remaja selalu minum air putih di setiap waktu setelah berolahraga, sebelum berangkat sekolah, pulang sekolah, sebelum tidur, dan ketika bangun tidur. Kebiasaan minum air putih ini akan menentukan kecukupan cairan tubuhnya. Semakin sering frekuensi minum air putih, maka kebutuhan cairan tubuh diduga akan tercukupi. Survey di Singapura menunjukkan 
sebanyak $70 \%$ remaja akan minum apabila merasa haus, dan sebenarnya ini sudah terlambat karena haus merupakan indikasi awal dari dehidrasi (13).

Jumlah air putih (dalam satuan gelas) yang biasa dikonsumsi subjek setiap hari berkisar antara 3-16 gelas dengan rata-rata 8 gelas baik pada remaja laki-laki maupun perempuan. Kategori kecukupan air berdasarkan pedoman umum gizi seimbang (PUGS) yaitu 8 gelas air setiap hari. Konsumsi air putih dikategorikan kurang jika minum air putih kurang dari 8 gelas per hari, cukup jika 8-12 gelas per hari, dan lebih jika minum air putih lebih dari 13 gelas per hari. Sebagian besar remaja $(55,4 \%)$ termasuk dalam kategori cukup minum air putih. Sebanyak 37,3\% di antaranya termasuk kurang dan hanya $7,2 \%$ remaja yang lebih dalam minum air putih. Pada kondisi fisiologis normal (sehat), tubuh akan mampu mengeluarkan kelebihan cairan baik melalui ginjal (urin) maupun melalui kulit (keringat). Jika dibandingkan dengan studi di negara lainnya, rata-rata jumlah air putih yang dikonsumsi pada subjek penelitian ini lebih tinggi, di Singapura rata-rata remaja perempuan minum air 5-6 gelas dan laki-laki minum 6-8 gelas dalam sehari (8). Studi di Hongkong menunjukkan hasil yang sama bahwa $50 \%$ subjek penelitiannya minum air kurang dari 8 gelas, dan bahkan $30 \%$ di antaranya minum kurang dari 5 gelas (13).

Selain membawa bekal makanan, beberapa siswa biasa membawa bekal minuman ke sekolah. Sebanyak $37,3 \%$ remaja biasa membawa bekal minuman 1-3 kali setiap minggu, dan 34,9\% remaja membawa bekal minuman 4-6 kali setiap minggu. Mereka membawa bekal ketika ada pelajaran olahraga atau ketika mengikuti kegiatan ekstrakurikuler hingga sore hari. Sebaliknya hanya $27,7 \%$ remaja yang tidak terbiasa membawa bekal minuman ke sekolah.

Selain air putih, remaja juga memiliki kebiasaan minum terhadap jenis minuman tertentu lainnya. Sebanyak $32,5 \%$ remaja sering mengonsumsi susu sebelum berangkat sekolah dan sebelum tidur (Tabel 1). Jenis susu yang dikonsumsi bervariasi dari susu bubuk, hingga susu cair kemasan. Sebanyak $28,9 \%$ remaja sering minum teh di pagi dan atau sore hari. Sirup biasa diminum oleh 13,2\% remaja pada waktu istirahat sekolah. Kurang dari 10\% remaja yang mengonsumsi minuman isotonik, softdrink, dan minuman lainnya.

Tabel 1. Sebaran remaja berdasarkan jenis minuman selain air putih

\begin{tabular}{lcc}
\hline \multicolumn{1}{c}{ Jenis minuman } & $\mathbf{n}$ & \% \\
\hline Susu & 27 & 32,5 \\
Teh & 24 & 28,9 \\
Sirup & 11 & 13,2 \\
Minuman isotonik & 8 & 9,6 \\
Softdrink & 6 & 7,2 \\
Lainnya & 7 & 8,4 \\
Total & $\mathbf{8 3}$ & $\mathbf{1 0 0}$ \\
\hline
\end{tabular}

\section{Asupan cairan tubuh dan kontribusinya dari makanan dan minuman}

Tubuh memperoleh cairan terutama dari konsumsi makanan (padat) dan minuman, serta sebagian kecil dari hasil metabolisme (14). Pada penelitian ini total asupan cairan adalah penjumlahan cairan yang berasal dari makanan dan minuman yang dikonsumsi menurut recall 2x24 jam. Recall dilakukan pada hari libur dan hari aktif sekolah, kemudian dihitung konsumsi rata-rata cairan dua hari tersebut. Ratarata asupan cairan pada remaja laki-laki sebesar $2939 \pm 922$ $\mathrm{ml}$ secara signifikan lebih banyak jika dibandingkan dengan remaja perempuan yaitu sebesar $2250 \pm 581 \mathrm{ml}(p<0,05)$ (Tabel 2). Studi di Jakarta dan Bandung menunjukkan hal yang sama, yaitu total asupan cairan laki-laki lebih besar (3591 ml) dibandingkan dengan perempuan (2713 ml) (15). Hal ini sejalan dengan Data National Health And Nutrition Examination Survey (NHANES) III di USA yang menunjukkan rata-rata asupan total cairan pada remaja (14-18 tahun) lakilaki sebesar $3400 \mathrm{ml}$ per hari dan perempuan sebesar 2500 $\mathrm{ml}$ per hari (14).

Total air tubuh tidak berbeda antara laki-laki dan perempuan sampai anak berusia 12 tahun, dan setelah itu laki-laki lebih banyak kandungan air tubuhnya dibandingkan perempuan (14). Total cairan tubuh antar individu tergantung dari komposisi massa tubuh aktif (lean body mass). Laki-laki mempunyai massa tubuh aktif lebih tinggi dibandingkan perempuan, sehingga kadar air tubuh laki-laki akan lebih tinggi. Perempuan dan kelompok lanjut usia berkurang kandungan air tubuhnya karena lebih rendah komposisi massa bebas lemak (fat-free mass) dan meningkatnya lemak tubuh (14).

Secara keseluruhan asupan cairan dari makanan menyumbang kurang lebih sebesar $25,3 \%$ terhadap total asupan cairan. Asupan cairan dari makanan sebesar 778 $\mathrm{ml}$ pada laki-laki, lebih tinggi dibandingkan pada perempuan yaitu sebesar $542 \mathrm{ml}(\mathrm{p}<0,05)$ (Tabel 2). Hasil penelitian di wilayah pantai Jakarta Utara dan di pegunungan Lembang Bandung berturut-turut menunjukkan rata-rata asupan cairan dari makanan sebanyak $726 \mathrm{ml}$ dan $706 \mathrm{ml}$ atau menyumbang 29,2\% total asupan cairan (15).

Kelompok pangan pokok menyumbang cairan terbesar dari makanan. Seluruh subjek mengonsumsi makanan pokok minimum dua kali dalam sehari. Asupan cairan dari makanan pokok pada remaja laki-laki (364 $\mathrm{ml})$ lebih tinggi dibanding perempuan $(213 \mathrm{ml})(p<0,05)$ karena konsumsi makanan pokok pada laki-laki lebih banyak (Tabel 2). Rata-rata kontribusi cairan dari pangan pokok sebesar 10,9\% dari total asupan cairan. Remaja laki-laki mengonsumsi nasi 1,5 kali lebih banyak dibanding perempuan. Kontribusi asupan cairan dari makanan pokok sebesar $10 \%$ pada laki-laki maupun perempuan.

Kontribusi asupan cairan terbesar kedua dari jenis makanan adalah makanan sepinggan (bakso, soto, lontong 
sayur, laksa, dan lain-lain). Lebih dari 50\% remaja mengonsumsi makanan sepinggan. Rata-rata asupan cairan dari makanan sepinggan pada laki-laki (177 ml) lebih tinggi dibanding perempuan (156 ml) $(p>0,05)$. Ratarata kontribusi cairan dari makanan sepinggan sebesar $6,5 \%$ dari total asupan cairan. Adapun asupan cairan dari bahan makanan lainnya termasuk dari sayur dan buah sangat kecil (6-70 ml). Rata-rata kontribusi cairan dari makanan lainnya antara $0,2-2,6 \%$ dari total asupan cairan (Tabel 2).

Perhitungan asupan cairan dari minuman berasal dari sepuluh kategori minuman yaitu air putih, teh, susu, sirup, kopi, jus buah, softdrink, minuman instan, dan minuman lain. Total asupan cairan dari minuman pada laki-laki sebesar $2162 \mathrm{ml}$, lebih tinggi dibanding perempuan yaitu sebesar $1708 \mathrm{ml}(p<0,05)$. Kontribusi cairan dari minuman tersebut pada laki-laki dan perempuan berturutturut sebesar $73,6 \%$ dan $75,9 \%$ dari total asupan cairan (Tabel 3).

Air minum (air putih) merupakan penyumbang cairan terbesar baik pada laki-laki (50,9\% atau $1495 \mathrm{ml})$ maupun perempuan (58,3\% atau $1312 \mathrm{ml})$. Kemudian asupan cairan dari minuman susu lebih tinggi pada laki- laki (220 ml) dibandingkan perempuan $(128 \mathrm{ml})(p<0,05)$. Asupan dari minuman teh tidak berbeda antara kedua kelompok yaitu sebesar $166 \mathrm{ml}$ pada laki-laki dan sebesar $134 \mathrm{ml}$ pada perempuan (Tabel 3). Jika dibandingkan dengan anjuran menurut PUGS bahwa asupan air minum sebanyak 8 gelas per hari atau sebesar 2000 ml, maka rata-rata asupan cairan dari air minum pada studi ini masih kurang.

Asupan cairan dari jenis minuman sirup pada remaja laki-laki (94 $\mathrm{ml}$ ) lebih tinggi dibanding perempuan (73 ml) $(p>0,05)$. Asupan cairan dari minuman lainnya seperti jus buah, kopi, minuman instan, dan minuman lain sangat kecil namun asupan kopi lebih besar pada laki-laki dibandingkan perempuan $(p<0,05)$. Kontribusi minuman selain air putih berkisar antara 0,1-6,6\% dari total asupan cairan. Survey di USA menunjukkan asupan cairan ke dalam tubuh sebesar $1764 \mathrm{ml}$ per hari, dengan rincian air putih $673 \mathrm{ml}$, susu $312 \mathrm{ml}$, teh dan kopi $360 \mathrm{ml}$, dan minuman ringan $420 \mathrm{ml}$ per hari (16).

Total asupan cairan pada remaja laki-laki secara signifikan lebih banyak dibandingkan dengan remaja perempuan $(p<0,05)$. Pada remaja laki-laki kontribusi asupan cairan dari makanan sebesar $26,5 \%$ dan minuman

Tabel 2. Rata-rata asupan cairan dan kontribusinya dari berbagai jenis makanan pada remaja laki-laki dan perempuan

\begin{tabular}{|c|c|c|c|c|c|c|}
\hline \multirow{2}{*}{ Jenis makanan } & \multicolumn{2}{|c|}{ Laki-laki } & \multicolumn{2}{|c|}{ Perempuan } & \multicolumn{2}{|c|}{ Total } \\
\hline & $\mathrm{ml}$ & $\%$ & $\mathrm{ml}$ & $\%$ & $\mathrm{ml}$ & $\%$ \\
\hline Makanan pokok* & $364 \pm 130$ & 12,4 & $213 \pm 93$ & 9,5 & $289 \pm 135$ & 10,9 \\
\hline Makanan sepinggan & $177 \pm 165$ & 6,0 & $156 \pm 114$ & 6,9 & $167 \pm 140$ & 6,5 \\
\hline Lauk hewani* & $85 \pm 39$ & 2,9 & $54 \pm 42$ & 2,4 & $70 \pm 39$ & 2,6 \\
\hline Lauk nabati & $18 \pm 22$ & 0,6 & $10 \pm 22$ & 0,4 & $14 \pm 22$ & 0,5 \\
\hline Sayur-sayuran & $77 \pm 90$ & 2,6 & $54 \pm 60$ & 2,4 & $66 \pm 76$ & 2,5 \\
\hline Buah-buahan & $19 \pm 50$ & 0,6 & $20 \pm 37$ & 0,9 & $20 \pm 44$ & 0,8 \\
\hline Makanan jajanan & $34 \pm 45$ & 1,2 & $28 \pm 31$ & 1,2 & $31 \pm 38$ & 1,2 \\
\hline Makanan lainnya & $4 \pm 6$ & 0,1 & $8 \pm 15$ & 0,4 & $6 \pm 12$ & 0,2 \\
\hline Total makanan* & $778 \pm 280$ & 26,5 & $542 \pm 28$ & 24,1 & $661 \pm 265$ & 25,3 \\
\hline Total cairan* & $2939 \pm 922$ & 100,0 & $2250 \pm 581$ & 100,0 & $2595 \pm 834$ & 100,0 \\
\hline
\end{tabular}

Keterangan : * signifikan $(p<0,05$; uji beda $t$-test $)$

Tabel 3. Rata-rata asupan cairan dan kontribusinya dari berbagai jenis minuman pada remaja laki-laki dan perempuan

\begin{tabular}{|c|c|c|c|c|c|c|}
\hline \multirow{2}{*}{ Jenis minuman } & \multicolumn{2}{|c|}{ Laki-laki } & \multicolumn{2}{|c|}{ Perempuan } & \multicolumn{2}{|c|}{ Total } \\
\hline & $\mathrm{ml}$ & $\%$ & $\mathrm{ml}$ & $\%$ & $\mathrm{ml}$ & $\%$ \\
\hline Air putih & $1495 \pm 745$ & 50,9 & $1312 \pm 514$ & 58,3 & $1400 \pm 638$ & 54,6 \\
\hline Susu* & $220 \pm 172$ & 7,5 & $128 \pm 143$ & 5,7 & $172 \pm 163$ & 6,6 \\
\hline Teh & $166 \pm 193$ & 5,6 & $134 \pm 154$ & 6,0 & $150 \pm 173$ & 5,8 \\
\hline Sirup & $94 \pm 156$ & 3,2 & $73 \pm 124$ & 3,2 & $83 \pm 140$ & 3,2 \\
\hline Jus buah & $59 \pm 138$ & 2,0 & $23 \pm 64$ & 1,0 & $40 \pm 107$ & 1,5 \\
\hline Softdrink & $38 \pm 112$ & 1,3 & $19 \pm 76$ & 0,9 & $28 \pm 98$ & 1,1 \\
\hline Kopi* & $37 \pm 65$ & 1,3 & $10 \pm 39$ & 0,4 & $23 \pm 55$ & 0,9 \\
\hline Minuman instan & $35 \pm 96$ & 1,2 & $5 \pm 34$ & 0,2 & $20 \pm 72$ & 0,7 \\
\hline Minuman lain & $18 \pm 62$ & 0,6 & $4 \pm 25$ & 0,2 & $9 \pm 43$ & 0,4 \\
\hline Total minuman* & $2162 \pm 922$ & 73,6 & $1708 \pm 513$ & 75,9 & $1927 \pm 704$ & 74,7 \\
\hline Total cairan* & $2939 \pm 922$ & 100,0 & $2250 \pm 581$ & 100,0 & $2595 \pm 834$ & 100,0 \\
\hline
\end{tabular}

Keterangan: * = signifikan $(p<0,05$; uji beda $t$-test $)$ 
sebesar 73,6\% (kontribusi dari air putih 50,9\%), sedangkan pada remaja perempuan berturut-turut sebesar $24,1 \%$ dan $75,9 \%$ (kontribusi dari air putih 58,3\%). Survey pada populasi dewasa di USA menunjukkan total asupan cairan sebesar $28 \%$ dari makanan, $28 \%$ dari air putih, dan $44 \%$ dari minuman lainnya (16).

\section{Kebutuhan cairan dan tingkat kecukupannya}

Kebutuhan cairan pada individu dengan kategori usia 15-30 tahun adalah $40 \mathrm{ml} / \mathrm{kg}$ BB (12). Sehingga kebutuhan cairan pada remaja laki-laki antara $1600-3200 \mathrm{ml}(2292 \pm 411$ $\mathrm{ml}$ ), dan pada remaja perempuan antara 1520-3200 ml (2057 $\pm 323 \mathrm{ml}$ ). Berdasarkan uji beda $t$-test terdapat perbedaan yang nyata $(p<0,05)$ antara kebutuhan cairan laki-laki dan perempuan. Kandungan lemak pada perempuan dua kali lebih banyak dibanding laki-laki, sehingga kebutuhan cairan perempuan secara umum akan lebih rendah dibanding lakilaki pada kategori usia yang sama (4). Institute of Medicine (IOM) melakukan perhitungan kebutuhan cairan berdasarkan estimasi total kehilangan cairan tubuh pada orang dewasa dengan aktivitas ringan yang berkisar antara 1050 - 3100 $\mathrm{ml}$ per hari (14).

Kecukupan terhadap kebutuhan cairan adalah perbandingan antara asupan cairan dengan kebutuhan cairan pada masing-masing individu (\%). Rata-rata asupan cairan antara remaja laki-laki dan perempuan berturut-turut sebesar $2939 \mathrm{ml}$ dan $2250 \mathrm{ml}$, sedangkan kebutuhannya berturut-turut sebesar $2292 \mathrm{ml}$ dan $2057 \mathrm{ml}$. Kecukupan kebutuhan cairan remaja laki-laki berkisar antara $74-304 \%$ (rata-rata $132 \pm 47 \%$ ), sedangkan remaja perempuan berkisar antara 46-203\% (rata-rata $111 \pm 33 \%$ ). Asupan, kebutuhan, dan kecukupan cairan pada remaja laki-laki secara signifikan lebih tinggi dibandingkan perempuan $(p<0,05)$ (Tabel 4).

Tabel 4. Rata-rata asupan, kebutuhan, dan kecukupan cairan remaja laki-laki dan perempuan

\begin{tabular}{lcc}
\hline Tingkat kecukupan & Laki-laki & Perempuan \\
\hline Asupan cairan $(\mathrm{ml})^{*}$ & $2939 \pm 922$ & $2250 \pm 581$ \\
Kebutuhan cairan $(\mathrm{ml})^{\star}$ & $2292 \pm 411$ & $2057 \pm 323$ \\
Kecukupan cairan $(\%)^{*}$ & $132 \pm 47$ & $111 \pm 33$ \\
\hline
\end{tabular}

Keterangan : * $=$ signifikan $(p<0,05$; uji beda $t$-test $)$

Kategori tingkat kecukupan cairan dikatakan kurang jika kurang dari 90\%, cukup jika sama dengan 90-110\%, dan lebih jika lebih dari $110 \%$, maka sebanyak $55,4 \%$ remaja termasuk dalam kategori lebih. Terdapat 20,5\% subjek berada pada kategori cukup asupan cairan, yaitu laki-laki sebesar $10,8 \%$ dan perempuan sebesar 9,6\%. Remaja dengan kategori kurang asupan cairan sebanyak $24,1 \%$, terdiri dari $16,9 \%$ perempuan dan hanya $7,2 \%$ laki-laki. Jika dibandingkan dengan kebiasaan minum air putih, masih terdapat $37,3 \%$ subjek yang minum kurang dari 8 gelas per hari.

\section{KESIMPULAN DAN SARAN}

Rata-rata total asupan cairan pada remaja laki-laki sebesar $2939 \pm 922 \mathrm{ml}$, sedangkan perempuan sebesar $2250 \pm 581 \mathrm{ml}$. Kontribusi asupan cairan dari makanan dan minuman terhadap total asupan cairan berturut-turut pada laki-laki sebesar $26,5 \%$ dan $73,6 \%$, sedangkan pada perempuan sebesar $24,1 \%$ dan $75,9 \%$. Kontribusi konsumsi air putih terhadap total asupan cairan sebesar $51 \%$ pada remaja laki-laki $(1495 \mathrm{ml})$ dan sebesar $58 \%$ pada perempuan $(1311 \mathrm{ml})$. Konsumsi rata-rata air putih tersebut masih kurang dari anjuran konsumsi 8 gelas per hari $(2000 \mathrm{ml})$.

Rata-rata kebutuhan cairan remaja laki-laki sebesar $2292 \pm 411 \mathrm{ml}$ dan perempuan sebesar $2057 \pm 323 \mathrm{ml}$. Rata-rata pemenuhan kebutuhan cairan laki-laki sebesar $132 \pm 47 \%$ dan perempuan sebesar $111 \pm 33 \%$. Terdapat perbedaan yang nyata $(p<0,05)$ antara kebutuhan, asupan, dan pemenuhan kebutuhan cairan, yaitu pada remaja lakilaki lebih tinggi dibandingkan perempuan.

Masih terdapat $37,3 \%$ remaja yang minum air putih kurang dari 8 gelas per hari dan sebesar $24,1 \%$ remaja yang asupan cairannya kurang dari $90 \%$ kebutuhan. Untuk itu perlu dilakukan penyuluhan minum air putih yang cukup pada remaja. Kegiatan tersebut lebih efektif dilakukan di sekolah melalui penyampaian yang terintegrasi dengan mata pelajaran terkait seperti biologi, lingkungan hidup, dan olahraga atau kesehatan. Selain itu perlu dilengkapi penyediaan sarana air minum (galon) di setiap ruang kelas yang dikelola bersama oleh siswa.

\section{UCAPAN TERIMA KASIH}

Penulis menyampaikan terima kasih kepada Kepala Sekolah dan Guru Bimbingan dan Penyuluhan (BP) SMAN 2 Kota Bogor yang telah memberikan ijin sehingga dapat melakukan penelitian ini. Demikian pula penghargaan yang tinggi disampaikan kepada seluruh siswa yang telah bersedia menjadi responden.

\section{RUJUKAN}

1. Mahan LK, Stump SE, editors. Krause's food, nutrition, and diet therapy. USA: Saunders; 2004.

2. Sawka MN, Mountain SJ. Fluid and electrolyte balance: effects on thermoregulation and exercise in the heat. In: Bowman BA Russel RM. Present knowledge in nutrition 8th eds. Washington: ILSI Press; 2001.

3. Sawka MN, Cheuvront SN, Carter R. Human water needs. Nutrition Reviews 2005; 63(6):S30-9.

4. Byrd-Bredbenner C. Wardlaw's perspective in nutrition. USA: McGrawHill; 2009.

5. Batmanghelidj F. Air untuk menjaga kesehatan dan menyembuhkan penyakit. Jakarta: Gramedia; 2007. 
6. Sawka MN, Burke LM, EichnerER, Maughan RJ, Mountain SJ, Stachenfeld SN. Exercise and fluid replacement. JAm Coll Sport Med 2007; 39(2): 377-90.

7. Proboprastowo SM, Dwiriani CM. Air dan elektrolit. Jakarta: Widyakarya Nasional Pangan dan Gizi VIII; 2004.

8. Temasek Polytechnic and AFIC (Asian Food Information Center). Singapore drinking habits survey. Singapore: Temasek Polytechnic and AFIC; 1998.

9. Departemen Kesehatan. Laporan nasional riset kesehatan dasar 2007. Jakarta: Depkes RI; 2008.

10. Hardinsyah, Soenaryo ES, Briawan D, Damayanti E, Dwiriani CM, Effendi YH, Dewi M, Aries M. Studi kebiasaan minum and status hidrasi pada remaja dan dewasa di dua wilayah ekologi yang berbeda. Bogor: Perhimpunan Peminat Gizi dan Pangan Indonesia (Pergizi Pangan) dan Departemen Gizi Masyarakat, FEMA-IPB; 2009.
11. Mahmud MK, Zulfianto NA. editor. Tabel komposisi pangan Indonesia. Jakarta: Elex Media Komputindo; 2009.

12. Food and Nutrition Research Institute (FNRI). Recommended energy and nutrient intakes. Phillippines: Food and Nutrition Research Institute; 2002.

13. Asia Food Information Center (AFIC). Fluid the forgotten factor. Singapore: Asia Food Information Center; 2002.

14. Institute of Medicine (IOM). Dietary reference intakes for water, potassium, sodium, chloride, and sulfate. USA: National Academic Press; 2004.

15. Briawan D, Hardinsyah, Sunaryo E. Fluids intake of adolescents living in mountanious and coastal areas. Paper was presented at the International Congress of Nutrition (ICN); 2009 October 1-9; Bangkok.

16. Kleiner SM. Water: an essential but overlooked nutrient. J Am Diet Asoc 1999: 99-102. 